\title{
Relationships between diatoms and the environment in Spanish reservoirs
}

\author{
A. I. Negro \& C. De Hoyos
}

Área de Ecología, Facultad de Biología. Universidad de Salamanca. Campus Miguel de Unamuno. 37071

Salamanca. España. E-mail: negro@usal.es

\begin{abstract}
Diatoms are very useful environmental indicators in limnological and paleolimnological studies. Spanish reservoirs offer a valuable opportunity for the study of relationships between diatoms and environmental conditions, since these ecosystems are abundant in this country and the patterns of their regional limnology are well established.

We report the results from a study carried out on diatom communities in 40 reservoirs from several Spanish water basins. More than 200 diatom taxa were found. A canonical correspondence analysis was applied to the abundance data of the most common taxa and the main physical and chemical variables. This analysis showed that mineralisation (conductivity and alkalinity) was the most important environmental factor explaining diatom distribution, while trophic state was the second most important. These results are similar to those in previous studies on phytoplankton in Spanish reservoirs. Conductivity and alkalinity optima of the selected taxa allow us to consider these taxa as good indicators of water mineral content in similar ecosystems.
\end{abstract}

Keywords: diatoms, reservoirs, water mineralisation, trophic state, canonical correspondence analysis

\section{RESUMEN}

Las diatomeas son indicadores ambientales muy útiles en estudios limnológicos y paleolimnológicos. En España los embalses ofrecen una gran oportunidad para el estudio de las relaciones entre las diatomeas y las condiciones ambientales, ya que son ecosistemas muy abundantes y las principales características de su limnología regional están bien estudiadas.

Se presentan aqui los resultados de un estudio sobre las comunidades de diatomeas efectuado en 40 embalses de diversas cuencas hidrográficas españolas. En ellos se encontraron más de 200 taxones de diatomeas. Se efectuó un análisis de correspondencias canónicas con los datos de abundancia de los taxones más frecuentes y las principales variables físico-químicas. Este análisis muestra que el factor con mayor influencia sobre las comunidades de diatomeas es la mineralización (conductividad y alcalinidad), y en segundo lugar el grado trófico. Estos resultados son similares a estudios previos sobre el fitoplancton de embalses españoles. Los valores de los óptimos respecto a la conductividad y alcalinidad de los principales taxones, permiten considerar dichos taxones como buenos indicadores del contenido mineral del agua en ecosistemas similares.

Palabras clave: diatomeas, embalses, mineralización del agua, estado trófico, análisis de correspondencias canónicas

\section{INTRODUCTION}

Diatoms are currently among the most studied organisms in freshwater ecosystems, due to their role as environmental indicators (Stoermer $\&$ Smol, 1999). The response of individual species to some environmental factors allow us to infer the magnitude of those factors considering only the community composition, which is especially useful in paleolimnology. With data from modern diatom communities we can calcu- late species' optima and tolerances (Charles, 1985; Cumming et al., 1995; Joynt \& Wolfe, 2001). These optima and tolerances serve to design transfer functions which, when applied to fossil diatom assemblages, allow us to estimate the magnitude of environmental factors over time (Stevenson et al., 1989; Battarbee et al., 1999; Enache \& Prairie, 2002). Sedimentdiatom records have revealed eutrophication processes (Lotter, 1998; Reavie et al., 2000), acidification (Tolonen \& Jaakkola, 1983; Jones 
et al., 1993; Dixit et al., 2002), land-use changes (Siver et al., 1999), and climate changes (Verschuren et al., 2000; Joynt \& Wolfe, 2001).

Generally, species optima and tolerances are calculated with data from a large number of lakes (as many as possible), covering a broad gradient range of environmental factors in the area. In Spain, where deep lakes are scarce, reservoirs offer a better opportunity for this type of studies.

The most extensive and detailed work performed in Spain on reservoir limnology is that of Margalef et al. (1976), who studied the physical and chemical variables, zooplankton, phytoplankton, and benthos in about one hundred reservoirs all over the country. A part of the phytoplankton data had been previously treated by Planas (1975). About fifteen years later, a second sampling was carried out in the same reservoirs, and their regional limnology was discussed by Armengol et al. (1991) and Riera et al. (1992). On the second occasion Sabater \& Nolla (1991) studied the phytoplankton community as a whole, and Sabater (1991) focussed on Centrales (Bacillariophyceae).

The present work deals with diatom communities in forty Spanish reservoirs from the main administrative water basins. The foremost objectives were: 1 . to study the most important factors affecting the distribution of the main diatom taxa; 2. to calculate the ecological opti$\mathrm{ma}$ and tolerances for these factors in some selected taxa so as to analyse their utility as local environmental indicators.

\section{STUDY SITES AND METHODS}

We studied 40 reservoirs located in the main administrative water basins of Spain: Duero, Ebro, Guadalquivir, Guadiana, Júcar, Miño, Segura, Tajo, Norte I, and Norte II (Table 1, Fig. 1).

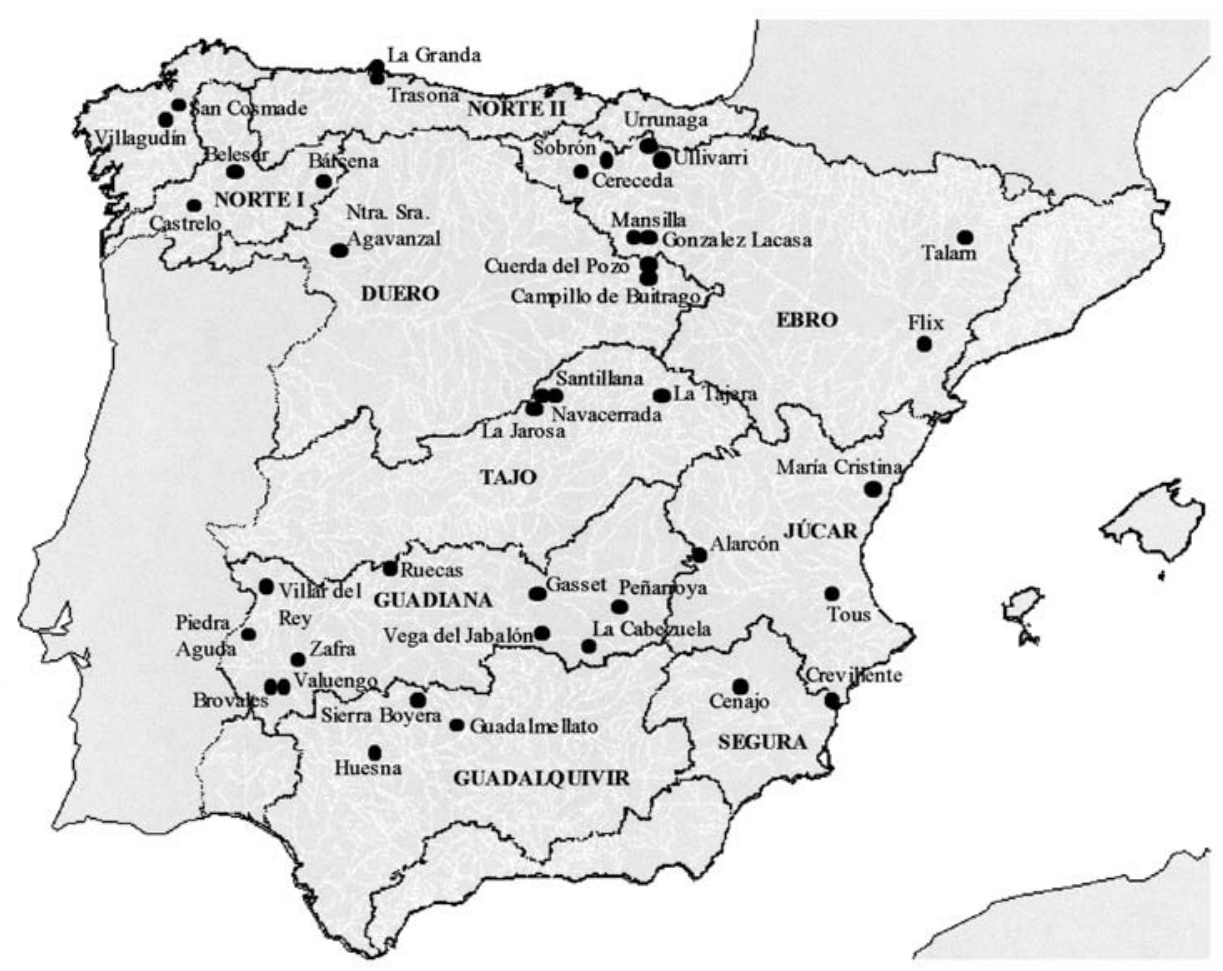

Figure 1. Distribution of the studied water reservoirs in the administrative Spanish water basins. Distribución de los embalses estudiados en las cuencas hidrográficas en las que se divide administrativamente el territorio español. 
Table 1. Names of the studied reservoirs, administrative water basins they belong to, number of phytoplankton samples taken for quantitative estimates $(\mathrm{N})$, and year of sampling in each reservoir. Nombre de los embalses estudiados, cuenca hidrográfica administrativa a la que pertenecen, número de muestras de fitoplancton utilizadas para estimaciones cuantitativas (N) y año de muestreo en cada embalse.

\begin{tabular}{|c|c|c|c|c|c|c|c|}
\hline Water basin & Reservoir name & $\mathbf{N}$ & Year & Water basin & Reservoir name & $\mathbf{N}$ & Year \\
\hline \multirow[t]{3}{*}{ Duero } & Agavanzal & 6 & 2000 & \multirow[t]{3}{*}{ Júcar } & Alarcón & 6 & 1999 \\
\hline & Campillo Buitrago & 8 & 2001 & & $\mathrm{M}^{\mathrm{a}}$ Cristina & 5 & 1999 \\
\hline & Cuerda del Pozo & 8 & 2001 & & Tous & 6 & 1999 \\
\hline \multirow[t]{8}{*}{ Ebro } & Cereceda & 6 & 1999 & \multirow[t]{6}{*}{ Norte I } & Belesar & 3 & 2001 \\
\hline & Flix & 6 & 1999 & & Bárcena & 6 & 2001 \\
\hline & Gonzalez La-Casa & 6 & 1999 & & Castrelo & 1 & 2001 \\
\hline & Mansilla & 6 & 1999 & & San Cosmade & 4 & 2000 \\
\hline & Sobrón & 6 & 1999 & & Villagudín & 3 & 2000 \\
\hline & Talarn & 6 & 1999 & & & & \\
\hline & Ullivarri & 4 & 2000 & \multirow[t]{2}{*}{ Norte II } & La Granda & 6 & 2000 \\
\hline & Urrunaga & 5 & 2000 & & Trasona & 6 & 2000 \\
\hline \multirow[t]{4}{*}{ Guadalquivir } & Guadalmellato & 13 & 2001 & \multirow[t]{3}{*}{ Segura } & Cenajo & 6 & 1999 \\
\hline & Huesna & 6 & 2000 & & Crevillente & 6 & 1999 \\
\hline & Sierra Boyera & 12 & 2001 & & & & \\
\hline & & & & \multirow[t]{11}{*}{ Tajo } & La Jarosa & 6 & 2000 \\
\hline \multirow[t]{10}{*}{ Guadiana } & Brovales & 6 & 1999 & & La Tajera & 4 & 2000 \\
\hline & Gasset & 9 & 2001 & & Navacerrada & 5 & 2000 \\
\hline & La Cabezuela & 9 & 2001 & & Santillana & 4 & 2000 \\
\hline & Peñarroya & 9 & 2001 & & & & \\
\hline & Piedra Aguda & 9 & 2001 & & & & \\
\hline & Ruecas & 5 & 2000 & & & & \\
\hline & Valuengo & 6 & 1999 & & & & \\
\hline & Vega de Jabalón & 9 & 2001 & & & & \\
\hline & Villar del Rey & 9 & 2001 & & & & \\
\hline & Zafra & 6 & 1999 & & & & \\
\hline
\end{tabular}

Sample collection and analyses of physical and chemical variables were performed by CEDEX (Centro de Estudios y Experimentación de Obras Públicas) staff. Temperature, $\mathrm{pH}$, conductivity, and oxygen were measured with portable meters. Alkalinity was measured by colorimetric titration (APHA-AWWA-WPCF, 1985). Ammonia was analysed using the Spectroquant 14752 method (detection limit of the method: $20 \mu \mathrm{gN} / \mathrm{l}$ ) and nitrates were determined using the Spectroquant 14773 method (detection limit: $230 \mu \mathrm{gN} / 1$ ), while for nitrites the Spectroquant 14776 was used (detection limit: $15 \mu \mathrm{gN} / \mathrm{l}$ ). Orthophosphates and total phosphorus (TP) were analysed using the ascorbic acid method (detection limit: $10 \mu \mathrm{gP} / 1)$. Water for orthophosphate determination was filtered immediately (GF/C filters) and stored in a freezer until analysed in the laboratory. Water for TP analysis was fixed with acid after sampling and was digested in the laboratory prior to analysis using a DR LANGE HT200S digestor in acidic conditions (APHA-AWWA-WPCF, 1985). Chlorophyll $a$ was determined using the formulae of Parsons \& Strickland (1963).

Table 2 shows the variation range and median value of the environmental variables analyzed, at the dates and depths included in the study. Some environmental data could not be measured as they were under the detection limit of the analytical method. For their inclusion in the analysis we considered a magnitude equal to one unit smaller than the detection limit in the case of orthophosphates, TP, ammonia, and nitrites, and ten units smaller in the case of nitrates. 
Table 2. Minimum, maximum, and median values of the physical and chemical variables in the data set for the forty reservoirs. Ab: abbreviation used in figure 2; N: number of samples. Valor mínimo, máximo y mediana de las variables físico-químicas para el conjunto de los 40 embalses. Ab: abreviatura utilizada en la figura 2; $N$ : número de muestras.

\begin{tabular}{llcccc}
\hline & Ab & Min & Max & Median & N \\
\hline Secchi depth $(\mathrm{m})$ & $\mathrm{Sec}$ & 0.1 & 9 & 1.8 & 250 \\
Alkalinity $(\mathrm{mg} \mathrm{CaCO} / \mathrm{l})$ & $\mathrm{Alk}$ & 12 & 296 & 108.5 & 240 \\
Temperature $\left({ }^{\circ} \mathrm{C}\right)$ & $\mathrm{Tem}$ & 3.9 & 29.3 & 17.4 & 252 \\
Dissolved oxygen $(\mathrm{mg} / \mathrm{l})$ & $\mathrm{Ox}$ & 0.2 & 31.68 & 8.6 & 252 \\
$\mathrm{pH}$ & $\mathrm{pH}$ & 5.7 & 9.6 & 8.1 & 252 \\
Conductivity $(\mu \mathrm{S} / \mathrm{cm})$ & $\mathrm{Cond}$ & 24 & 1677 & 290 & 252 \\
Ammonia $(\mu \mathrm{g} \mathrm{N} / \mathrm{l})$ & $\mathrm{NH} 4$ & $<10$ & 510 & $40-50$ & 243 \\
Nitrite $(\mu \mathrm{g} \mathrm{N} / \mathrm{l})$ & $\mathrm{NO} 2$ & $<10$ & 150 & $20-30$ & 244 \\
Nitrate $(\mu \mathrm{g} \mathrm{N} / \mathrm{l})$ & $\mathrm{NO} 3$ & $<200$ & 3730 & $400-600$ & 250 \\
Soluble reactive phosphorus $(\mu \mathrm{g} \mathrm{P} / \mathrm{l})$ & $\mathrm{SRP}$ & $<10$ & 250 & $<10$ & 196 \\
Total phosphorus $(\mu \mathrm{g} \mathrm{P} / \mathrm{l})$ & $\mathrm{TP}$ & $<10$ & 1668 & $40-50$ & 226 \\
Chlorophyll $a\left(\mathrm{mg} / \mathrm{m}^{3}\right)$ & $\mathrm{Chl}$ & 0.06 & 75.24 & 3.61 & 171 \\
\hline
\end{tabular}

We examined phytoplankton samples taken on three or four occasions (winter, spring, summer, and autumn) from each reservoir in 1999, 2000, or 2001 (Table 1). Samples were taken at two sampling points: near the dam (P1), and near the river inflow (P2). In some Guadiana reservoirs and those of the Ebro, Júcar, Tajo, Segura, and Norte II water basins, epilimnion samples were combined. The rest of the reservoir samples were collected generally at 2 and $5 \mathrm{~m}$ depth at $\mathrm{P} 1$, and at $2 \mathrm{~m}$ depth at $\mathrm{P} 2$. Net samples were also taken from most of the reservoirs so as to help in taxa identification. Phytoplankton counts were performed using an inverted microscope according to the Utermöhl method (Utermöhl, 1958). As many fields as necessary were counted to obtain a significant cell number (Sournia, 1978). The magnification was from 100x to $1000 \mathrm{x}$, depending on the size and density of each taxon. The results were expressed as cells per ml.

Diatom taxonomy follows Krammer \& Lange-Bertalot (1991a, b; 1997a, b). Taxa were generally identified to species or variety level.

A Canonical Correspondence Analysis (CCA) was carried out using the CANOCO package (Ter Braak \& Smilauer, 1998) with the environmental variables shown in Table 2 and the diatom taxa listed in Table 3. The CCA detects variation pat- terns within the species data that can be explained best by the environmental variables considered (Ter Braak, 1986). In this analysis it is assumed that the species have a unimodal response to environmental variables, which can be previously checked by the Detrended Correspondence Analysis (Ter Braak \& Smilauer, 1998). A strong unimodal response can be deduced if the maximum gradient length of the Detrended Correspondence Analysis exceeds $4 \mathrm{SD}$, as it occurred in our study.

Only taxa present in $10 \%$ or more of the reservoirs were included in the CCA, except for those with maximum population density lower than $1 \mathrm{cell} / \mathrm{ml}$. The selected taxa are shown in Table 3. The number of samples considered in the analysis was 252 . The data for some environmental variables were not available in all samples (Table 2). Physical and chemical data (except for $\mathrm{pH}$ ), and diatom data were logarithmically transformed $(\log [\mathrm{x}+1])$. The statistical significance of the ordination axes was assessed by the Monte Carlo permutation tests (999 permutations).

In the CCA ordination diagrams, the species' position approximately indicates the environmental optima for each species relative to the other taxa (Ter Braak, 1986). The CCA is a 
Table 3. Names of the main taxa in this study. Ab: abbreviations used in figures 2 and 3. N: number of quantitative samples where each taxon occurred. Max: maximum number of individuals counted (cells $/ \mathrm{ml}$ ). The most abundant and/or commonest taxa are marked with an asterisk. Nombre de los principales taxones del estudio. Ab: abreviatura utilizada en las figuras 2 y 3. N: número de muestras cuantitativas donde apareció cada taxón. Máx: número de individuos máximo encontrado (células/ml). Se señalan con un asterisco los taxones más abundantes y/o frecuentes.

\begin{tabular}{|c|c|c|c|c|c|c|c|}
\hline Name & $\mathbf{A b}$ & $\mathbf{N}$ & Max & Name & $\mathbf{A b}$ & $\mathbf{N}$ & Max \\
\hline \multirow{2}{*}{$\begin{array}{l}\text { Achnantes lanceolata (Bréb.) Grun. } \\
\text { in } \mathrm{Cl} \text { \& \& Grun. } 1880\end{array}$} & \multirow[t]{2}{*}{ Acl } & \multirow[t]{2}{*}{5} & \multirow[t]{2}{*}{21.9} & *F. ulna (Nitzsch) Lange-Bertalot 1980 & Ful & 62 & 46.3 \\
\hline & & & & *F. ulna var. acus Kütz. Lange-Bertalot 1980 & $\mathrm{Fac}$ & 54 & 4327.3 \\
\hline *A. minutissima Kütz. 1833 & Acm & 72 & 552.7 & Gomphonema acuminatum Ehr. 1832 & $\mathrm{Gac}$ & 6 & 29.1 \\
\hline Amphora ovalis parvulum (Kütz.) Kütz. 1844 & Amo & 10 & 11.7 & G. clevei Fricke 1902 & $\mathrm{Gcl}$ & 8 & 32.7 \\
\hline Anomoeoneis vitrea (Grun.) Ross 1966 & Anvi & 8 & 7.5 & G. olivaceum (Hornemann) Bréb. 1838 & Gol & 10 & 17.4 \\
\hline *Asterionella formosa Hassall 850 & Asfo & 80 & 5615.6 & G. parvulum (Kütz.) Kütz. 1849 & Gpa & 4 & 21.4 \\
\hline *Aulacoseira distans (Ehr.) Simonsen 1979 & Audi & 37 & 5077.3 & *Gyrosigma acuminatum (Kütz.) Rabh 1853 & Gya & 30 & 1.4 \\
\hline *A. granulata (Ehr.) Simonsen 1979 & \multicolumn{2}{|c|}{ Augr 143} & 5136.2 & \multirow{2}{*}{$\begin{array}{l}\text { Hantzschia amphioxys (Ehr.) Grun. } \\
\text { in Cl. \& Grun. } 1880\end{array}$} & \multirow[t]{2}{*}{ Ham } & \multirow[t]{2}{*}{10} & \multirow[t]{2}{*}{1.1} \\
\hline Caloneis amphisbaena (Bory) Cl. 1894 & Caam & 6 & 7.8 & & & & \\
\hline C. silicula (Ehr.) Cl. 1894 & Casi & 4 & 1.4 & Meridion circulare (Grev.) Agardh 1831 & Mcir & 8 & 5.2 \\
\hline Cocconeis pediculus Ehr. 1838 & Cpe & 11 & 13.2 & Navicula capitata Ehr. 1838 & $\mathrm{Nc}$ & 7 & 8.8 \\
\hline C. placentula Ehr. 1838 & $\mathrm{Cpl}$ & 20 & 47.3 & *N. capitatoradiata Germain 1981 & Nca & 30 & 14.7 \\
\hline \multirow{2}{*}{$\begin{array}{l}\text { *Cyclotella comensis Grun. } \\
\text { in Van Heurck } 1882\end{array}$} & \multirow[t]{2}{*}{ Cco } & \multirow[t]{2}{*}{28} & \multirow[t]{2}{*}{12655.5} & N. cryptocephala Kütz. 1844 & Ncry & 9 & 5.7 \\
\hline & & & & N. cuspidata (Kütz.) Kütz. 1844 & Ncus & 10 & 6.6 \\
\hline${ }^{*}$ C. meneghiniana Kütz. 1844 & Cme & 21 & 1045.0 & N. lanceolata (Agardh) Ehr. 1838 & $\mathrm{Nla}$ & 6 & 21.5 \\
\hline *C. ocellata Pantocsek 1901 & $\mathrm{Coc}$ & 75 & 41364.1 & *N. margalithii Lange-Bertalot 1985 & Nma & 29 & 12.5 \\
\hline \multirow{2}{*}{$\begin{array}{l}\text { *C. stelligera Cl. \& Grun. } \\
\text { (in Van Heurck) } 1882\end{array}$} & \multirow[t]{2}{*}{ Cst } & \multirow[t]{2}{*}{18} & \multirow[t]{2}{*}{535.8} & *N. phyllepta Kütz. 1844 & $\mathrm{Nph}$ & 41 & 37.9 \\
\hline & & & & N. pupula Kütz. 1844 & Npup & 12 & 32.4 \\
\hline Cymatopleura elliptica (Bréb.) W. Sm. 1851 & Cye & 13 & 3.4 & N. radiosa Kütz. 1844 & Nrad & 16 & 16.1 \\
\hline${ }^{*}$ C. solea (Bréb.) W. Sm. 1851 & Cys & 27 & 3.3 & N. trivialis Lange-Bertalot 1980 & Ntri & 12 & 67.1 \\
\hline Cymbella affinis Kütz. 1844 & Caf & 8 & 11.7 & *Nitzschia acicularis (Kütz.) W. Sm. 1853 & $\mathrm{Nac}$ & 89 & 365.3 \\
\hline C. aspera (Ehr.) Peragallo 1849 & Cas & 6 & 1.5 & N. angustata (W. Sm.) Grun. & Nan & 11 & 7.2 \\
\hline C. helvetica Kütz. 1844 & Che & 7 & 11.3 & in Cl. \& Grun. 1880 & & & \\
\hline C. microcephala Grun. in Van Heurck 1880 & Cmic & 18 & 25.5 & N. dissipata (Kütz.) Grun. 1862 & Ndi & 20 & 9.7 \\
\hline C. minuta Hilse ex Rabh. 1862 & $\mathrm{Cmi}$ & 18 & 85.2 & N. flexa Schumann 1862 & $\mathrm{Nfl}$ & 12 & 3.0 \\
\hline *C. silesiaca Bleisch in Rabh. 1864 & Csi & 23 & 24.1 & N. linearis (Agardh) W. Sm. 1853 & Nli & 13 & 32.2 \\
\hline C. sinuata Gregory 1858 & Csin & 4 & 14.4 & *N. palea (Kütz.) W. Sm. 1856 & Npa & 11 & 3519.1 \\
\hline Diatoma moniliformis Kütz.1833 & Dmo & 18 & 14.8 & N. recta Hantz. in Rabh 1861-1879 & Nre & 7 & 2.94 \\
\hline *D. tenuis Agardh 1812 & Dte & 7 & 102.8 & N. vermicularis (Kützh) Hantz. in Rabh 1860 & Nve & 16 & 7.2 \\
\hline *D. vulgaris Bory 1824 & Dvu & 26 & 16.1 & *Stephanodiscus hantzschii Grun. & Shan & 52 & 103509.8 \\
\hline Fragilaria arcus (Ehr.) Cl. 1898 & Far & 9 & 8.0 & in Cl. \& Grun. 1880 & & & \\
\hline *F. capucina Desmazières 1925 & Fca & 43 & 596.7 & Surirella angusta Kütz. 1844 & Suan & 9 & 14.3 \\
\hline *F. crotonensis Kitton 1869 & Fcro & 49 & 24156.1 & *Tabellaria fenestrata (Lyngb.) Kütz. 1844 & Tfen & 17 & 457.3 \\
\hline F. tenera (W. Sm.) Lange-Bertalot 1980 & Fte & 13 & 581.3 & T. flocculosa (Roth) Kütz. 1844 & Tflo & 7 & 27.8 \\
\hline
\end{tabular}

method based on weighted averaging (WA). In WA, the optimum for an environmental factor of a species is estimated as the average of the values of this factor, at the sites where the species occurred, weighted by its abundance (Ter Braak, 1986, 1987): $\mathrm{u}_{\mathrm{k}}$ : optimum of species $\mathrm{k}$.

$\mathrm{y}_{\mathrm{ki}}$ : abundance of species $\mathrm{k}$ at site $\mathrm{i}$.

$\mathrm{x}_{\mathrm{i}}$ : value of the environmental factor at site $\mathrm{i}$.

The tolerance of a species can be estimated as the weighted-average standard deviation:

$$
\mathrm{t}_{\mathrm{k}}=\left(\sum \mathrm{y}_{\mathrm{ik}}\left(\mathrm{x}_{\mathrm{i}}-\mathrm{u}_{\mathrm{k}}\right)^{2 / \Sigma} \mathrm{y}_{\mathrm{ik}}\right)^{1 / 2}
$$




\section{RESULTS}

\section{Relevant taxa}

We found 40 diatom genera, both in quantitative and net samples, 215 species and varieties (32 Centrales and 183 Pennales). The major part of the taxa belonged to Navicula (27 taxa), Cymbella (25 taxa), Nitzschia (22 taxa), Fragilaria (19 taxa), and Cyclotella (13 taxa).

Some species of the remaining genera, such as Acanthoceras zachariasii, Actinocyclus normanii, Ellerbeckia arenaria, Pleurosira laevis, and Campilodiscus hibernicus, only appeared in reservoirs of the Ebro basin and in the SE part of Spain. Pinnularia and Eunotia taxa, i.e. Pinnularia viridis, P. subcapitata, and Eunotia bilunaris, were very scarce and occurred mainly in reservoirs in the west. Also Frustulia rhomboides and Neidium affine were found in the west.

The most common taxa and those with important population densities are shown in Table 3. We find among them Achnantes minutissima, Asterionella formosa, Aulacoseira granulata, most of Cyclotella species, Fragilaria capucina, F. crotonensis, F. ulna, F. ulna var. acus, Nitzschia acicularis, Stephanodiscus hantzschii, and Tabellaria fenestrata.

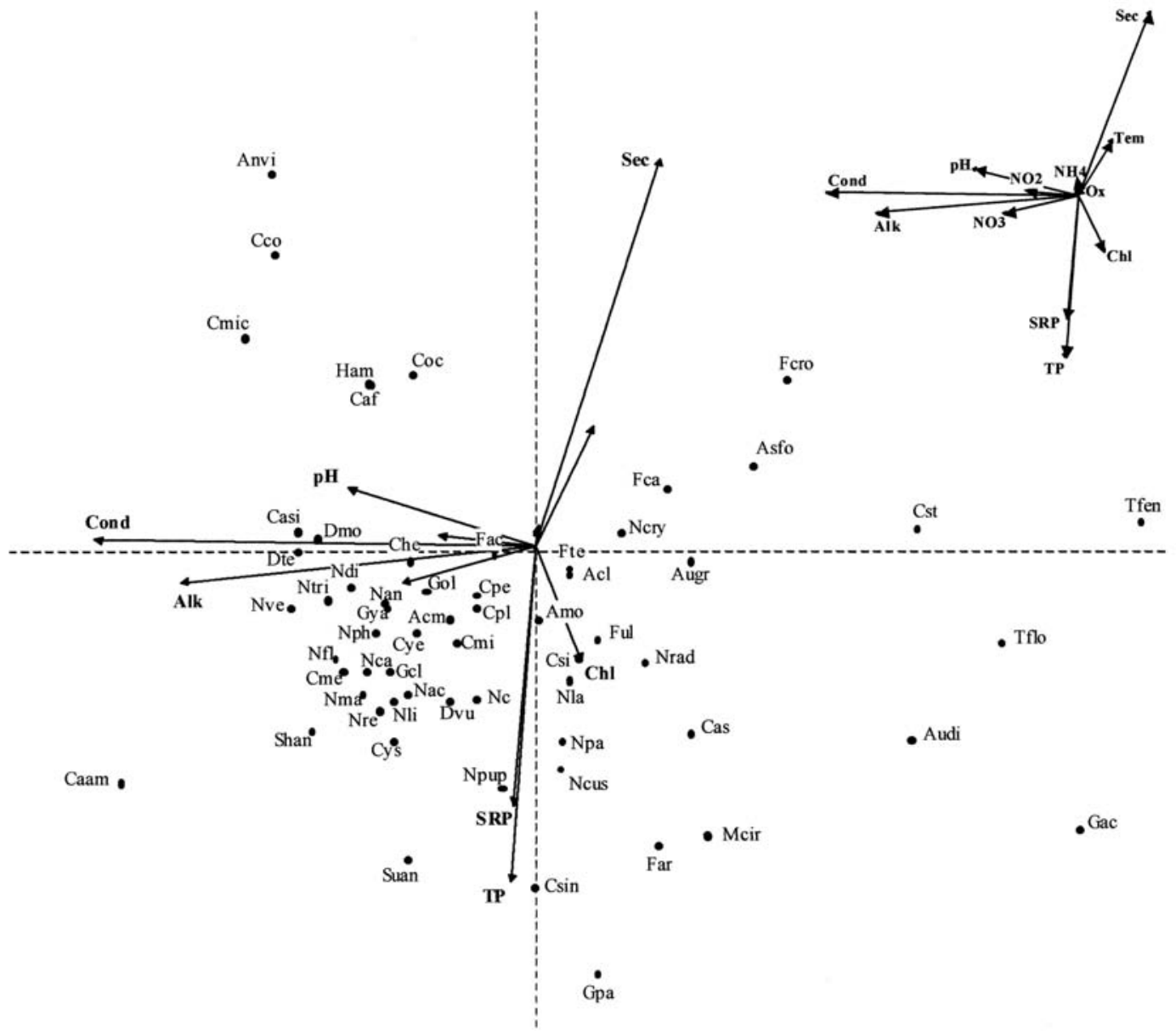

Figure 2. CCA biplot of the environmental variables (arrows) and species (points). Only the most important variables are labelled. The complete plot of the environmental variables is shown in the upper-right-hand corner of the figure. See tables 2 and 3 for abbreviations. Representación gráfica de los resultados del ACC, variables ambientales (flechas) y las especies (puntos). Solamente se señala el nombre de las variables más importantes. En el ángulo superior derecho se muestra el diagrama completo de las variables ambientales. Abreviaturas como en las tablas 2 y 3 . 
Diatoma, Gyrosigma and Cymatopleura species were also common, mainly in reservoirs of Ebro, Júcar, Segura, and in some of the Guadiana reservoirs, but their population densities were generally low.

\section{Canonical Correspondence Analysis}

The eigenvalues of the first two CCA axes were 0.34 and 0.22 respectively. These two axes collectively explain $10.3 \%$ of the variance in the diatom species data (axis 1: 6.3\%; axis 2: 4\%). The species-environment correlation was 0.82 for axis 1 and 0.64 for axis 2, and the amount of species-environment variance explained was $36.4 \%$ and $23.2 \%$ respectively. The first canonical axis and the sum of all canonical axes were statistically significant $(\mathrm{p}=0.001)$.

The first axis represents the mineral-content gradient, as it is strongly correlated to conductivity $(\mathrm{r}=-0.942)$ and alkalinity $(\mathrm{r}=-0.757)$. Also $\mathrm{pH}$ is associated with the first axis $(\mathrm{r}=-0.398)$. The second axis is related to the trophic gradient: Secchi depth and total phosphorus show the highest correlation to this axis $(\mathrm{r}=0.769$ and $\mathrm{r}=-0.667$ respectively). Chlorophyll $a$ and SRP are also related to the second axis, but correlation coefficients are lower ( $\mathrm{r}=-0.231$ for chlorophyll $a$ and $\mathrm{r}=-0.517$ for SRP).

Figure 2 shows the CCA biplot of environmental variables and diatom scores for the first two axes. Most of the taxa appear in the lower-left quadrant of the CCA, i.e. they are related to intermediate to high levels of mineral content and trophic state.

The species associated with higher values of the mineral-content gradient (i.e. with a more extreme position in the left part of the first CCA axis) were Caloneis amphisbaena, Cymbella microcephala, Cyclotella comensis, Anomoeoneis vitrea, Nitzschia vermicularis, Diatoma tenuis, Caloneis silicula, D. moniliformis, Stephanodiscus hantzschii, Navicula trivialis, Nitzschia flexa, and Cyclotella meneghiniana. Whereas those associated with the lower gradient values were Tabellaria fenestrata, Gomphonema acuminatum, Tabe- llaria flocculosa, Aulacoseira distans, Cyclotella stelligera, Fragilaria crotonensis, and Asterionella formosa.

With regard to the second axis (trophic gradient), Gomphonema parvulum, Cymbella sinuata, Surirella angustata, Fragilaria arcus, Meridion circulare, Gomphonema acuminatum, Navicula pupula, Caloneis amphisbae$n a$, and Navicula cuspidata, seemed to be related to the highest trophic level. In contrast, Anomoeoneis vitrea, Cyclotella comensis, Cymbella microcephala, Cyclotella ocellata, Fragilaria crotonensis, Cymbella affinis, and Hantzschia amphyoxis were in the lower extreme of the trophic gradient in the CCA biplot.

\section{Optima and tolerances}

Optima and tolerances for conductivity and alkalinity were calculated, since they were the variables revealed in the CCA as the most important ones explaining diatom distribution. We only considered the 24 taxa that developed dense populations and/or were very common (w/asterisk in Table 3). The optima and tolerances of these taxa are represented graphically in figure 3 in order of decreasing optima.

Both conductivity and alkalinity optima are quite different for the 24 selected taxa. As was to be expected, the arrangement of the taxa in figure 3 resembles the one of the CCA biplot. Thus, the taxa with the lowest alkalinity and conductivity optima are Tabellaria fenestrata, Aulacoseira distans, Cyclotella stelligera, Fragilaria crotonensis, and Asterionella formosa; whereas the highest optima are for Cyclotella comensis, C. meneghiniana, Diatoma tenuis, Stephanodiscus hantzschii, and Navicula margalithii.

The range of the alkalinity tolerance intervals was very similar for the 24 selected taxa. There were greater differences in conductivity. We could mention Cyclotella stelligera, Aulacoseira distans, and Tabellaria fenestrata, as those having the narrowest conductivity tolerance. Diatoma tenuis showed narrow tolerance for both variables. 

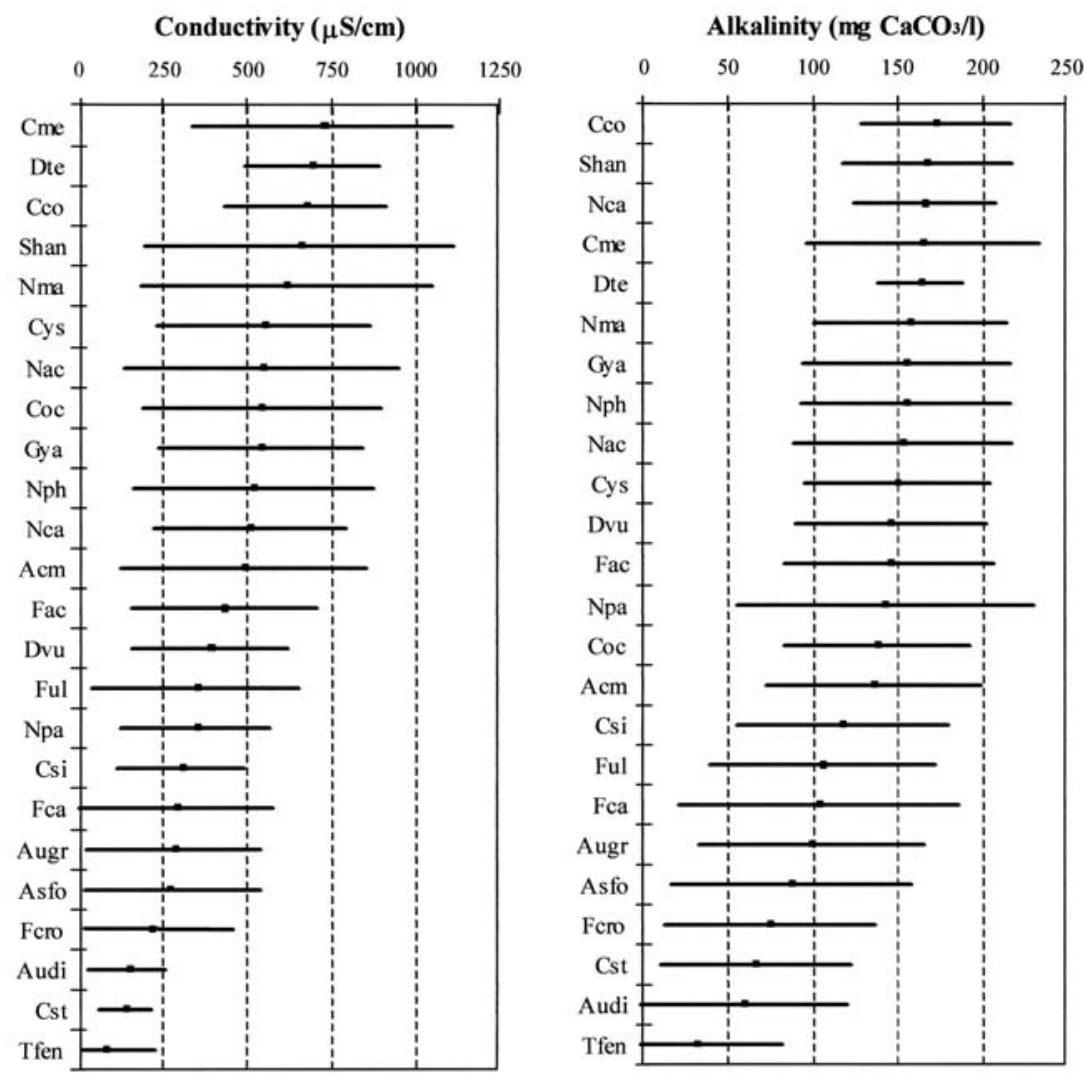

Figure 3. Alkalinity and conductivity optima (points) and tolerances (bars) of the 24 most relevant taxa, arranged in order of decreasing optima for conductivity and alkalinity. See Table 3 for abbreviations. Óptimos (puntos) y tolerancias (barras) respecto a la conductividad y alcalinidad, de los 24 taxones más importantes del estudio. Se representan en orden decreciente de los óptimos. Abreviaturas como en la Tabla 3.

\section{DISCUSSION}

It has been demonstrated, on a broad geographic scale, that phytoplankton in Spanish reservoirs is mainly influenced by the water mineral content and trophic state (Margalef et al., 1976; Sabater \& Nolla, 1991; Riera et al., 1992; De Hoyos et al., in press), and this again becomes apparent in our study. The ionic composition will probably always be the most important of the two factors because it depends on bedrock geology and climate (Margalef et al., 1976; Riera et al., 1992).

Margalef et al. (1976) divided Spanish reservoirs, according to the water mineral content, into two basic groups: 1) soft-water reservoirs, on siliceous bedrock (West part of the Iberian Peninsula), and 2) hard-water reservoirs, on calcareous bedrock (Central and Eastern part of the Iberian Peninsula). Only the taxa-presence/absence data in our study, without considering any other ones, had already revealed a difference between the two groups of reservoirs. Genera, such as Acanthoceras, Actinocyclus, Ellerbeckia, Campilodiscus, Cymatopleura, Gyrosigma, and Pleurosira, were much more common (and some of them exclusive) in the eastern reservoirs. Eunotia, Pinnularia, Frustulia, and Neidium, appeared mainly in the west area. The latter genera are very common in soft-water mountain lakes (De Hoyos \& Negro, 2001; Negro et al., 2003). 
Regarding the influence of the water mineral content on the most relevant taxa (first CCA axis), our results are consistent with those of other authors. That is to say, Asterionella formosa, Aulacoseira distans, Fragilaria crotonensis, Tabellaria fenestrata, and T. flocculosa, can be considered to be related to soft waters, which was also shown by Margalef et al. (1976) and Sabater \& Nolla (1991). Negro et al. (2000) reported that $T$. fenestrata and A. formosa contributed to the major part of the phytoplankton biomass during the circulation period in the Valparaíso Reservoir (Duero basin), where mean conductivity was only $24 \mu \mathrm{S} / \mathrm{cm}$. In the CCA biplot, Aulacoseira granulata is in an intermediate position, which reflects its wide distribution in the Spanish reservoirs (Sabater, 1991). Cyclotella stelligera prefers waters with a lower $\mathrm{pH}$ level and a lower calcium concentration than other Cyclotella species, such as Cyclotella meneghiniana and C. ocellata (Dixit et al., 2002; Enache \& Prairie, 2002). This can be seen in the CCA biplot (Fig. 1). In the Spanish reservoirs with the hardest water, C. meneghiniana, C. radiosa, and C. comensis are abundant, and Stephanodiscus hantzschii and Cyclostephanos dubius also occur but are more sporadic (Margalef et al., 1976; Sabater, 1991; Sabater \& Nolla, 1991). In our study C. radiosa (not included in the CCA analysis) was less common than $C$. comensis or C. meneghiniana, whereas $C$. ocellata was more common. On the other hand, Stephanodiscus hantzschii as well as other Stephanodiscus species and C. dubius also occurred in the hard-water reservoirs. But, because of their low occurrence and identification problems, we did not include Stephanodiscus spp. and C. dubius in the CCA.

Conductivity and alkalinity optima differed between the selected taxa, indicating that they could be considered as good mineral-content indicators. This is of great interest in paleolimnological studies, because water conductivity variation can be related to changes in patterns of precipitation and evaporation and thus to climate changes (Anderson et al., 1999; Verschuren et al., 2000).
Besides a well-defined optimum, a good environmental indicator must have a narrow tolerance, because taxa with broad tolerance will not be affected by changes in the environment (Racca et al., 2001; Enache \& Prairie, 2002). The tolerances we have obtained do not differ very much, especially for alkalinity. Nevertheless, it must be emphasized that the tolerances of taxa showing the highest optima hardly overlapped those of the taxa with the lowest optima (Fig. 3).

Regarding the relationship between diatoms and trophic state (second CCA axis), our results on soft-water reservoirs differ slightly from other studies. Namely, A. granulata, A. formo$s a$, and $F$ crotonensis are generally considered to be eutrophic species (Margalef et al., 1976; Carney, 1982; Lepistö \& Roseström, 1998; Reavie et al., 2000). In our study, F. crotonensis is in the lowest extreme of the trophic gradient (Fig. 2), and A. granulata and A. formosa (particularly the former) are near the center of the gradient. Conversely, Aulacoseira distans, a species abundant in oligotrophic lakes (De Hoyos, 1996), seems to prefer waters with a higher trophic state than the three species mentioned, as seen from their position in the CCA biplot. Some studies have pointed out that Spanish reservoirs are becoming increasingly eutrophic, especially the soft-water ones (Sabater \& Nolla, 1991; De Hoyos et al., 2004). Eutrophication-indicator diatoms could be useful tools for future management of these reservoirs, so our results need to be confirmed in further studies. In hard-water reservoirs, the main taxa did show the expected relation with trophic state. Stephanodiscus hantzschii is in the upper extreme of the trophic gradient (Fig. 2). Other Stephanodiscus species and Cyclostephanos dubius sometimes occur together with $S$. hantzschii. In lakes of eutrophic conditions Stephanodiscus spp. and C. dubius are common (Carney, 1982; Lotter, 1998; Temponeras et al., 2000; Reavie et al., 2000). Cyclotella species in hard-water reservoirs mainly inhabit the oligo-mesotrophic ones (Dasí et al., 1998), as it occurred in our study. 


\section{CONCLUSIONS}

Water mineral content appears, once again, as the most important factor explaining phytoplankton distribution in Spanish reservoirs.

Some of the most common and abundant diatoms in the reservoirs can be considered as good mineral-content indicators, which is very useful, especially in paleolimnological studies. The alkalinity and conductivity optima of these taxa are well defined, but the extreme values of tolerances require a more precise determination.

Variables related to trophic state also influence diatom communities, but in soft-water reservoirs it is difficult to determine the indicator taxa. A more detailed study on these reservoirs is of great interest, in order to find the best trophic-state indicators for their management.

\section{ACKNOWLEDGEMENTS}

This study was carried out within the framework of collaboration agreements between CEDEX and the University of Salamanca for the study of phytoplankton in water reservoirs. We would like to thank the CEDEX staff for contributing the physical and chemical data.

\section{REFERENCES}

ANDERSON, N.J., O. BENNIKE, K. CHRISTOFFERSEN, E. JEPPENSEN, S. MARKAGER, G. MILLER \& I. RENBERG. 1999. Limnological and palaeolimnological studies of lakes in south-western Greeenland. Geology of Greenland Survey Bulletin, 183: 68-74.

APHA-AWWA-WPCF. 1985. Standard Methods for the Examination of Water and Wasterwater. Amer. Publ. Health Ass. 16 ${ }^{\text {th }}$ ed. Washington. 1268 pp.

ARMENGOL, J., J. L. RIERA \& J. A.MORGUÍ. 1991. Major ionic composition in the Spanish reservoirs. Verh. Internat. Verein. Limnol., 24: 1363-1366.

BATTARBEE, R. W., D. F. CHARLES, S. S. DIXIT \& I. RENBERG. 1999. Diatoms as indicators of surface water acidity. In: The Diatoms: Applications for the Environmental and Earth Sciences.
Stoermer, E. F. \& J. P. Smol (eds.): 85-127. Cambridge University Press, Cambridge, U.K.

CARNEY, H. J. 1982. Algal dynamics and trophic interactions in the recent history of Frains Lake, Michigan. Ecology, 63(3): 1814-1826.

CHARLES, D. 1985. Relationships between surface sediment diatom assemblages and lakewater characteristics in Adirondack Lakes. Ecology, 66(3): 994-1011.

CUMMING, B. F., S. E. WILSON, R. I. HALL \& J. P. SMOL. 1995. Diatoms from British Columbia (Canada) Lakes and Their Relationship to Salinity, Nutrients and Other Limnological variables. Bibliotheca Diatomologica, Band 31. Lange-Bertalot, $\mathrm{H}$. (ed.). J. Cramer. Berlin-Stuttgart, $207 \mathrm{pp}$.

DASÍ, M. J., M. R. MIRACLE, A. CAMACHO, J. M. SORIA \& E. VICENTE. 1998. Summer phytoplankton assemblages across trophic gradients in hardwater reservoirs. Hydrobiologia, 369/370: 27-43.

DE HOYOS, C. 1996. Limnología del Lago de Sanabria. Variabilidad interanual del fitoplancton. Tesis doctoral. Universidad de Salamanca. 438 pp.

DE HOYOS, C. \& A. I. NEGRO. 2001. El Fitoplancton. En: Las lagunas del Parque Regional de la Sierra de Gredos. Toro, M. e I. Granados (eds.): 79-103. Monografías de la Red de Espacios Naturales de Castilla y León. Serie Técnica: Junta de Castilla y León. Valladolid.

DE HOYOS, C., A. I. NEGRO \& J. J. ALDASORO. 2004. Cianobacteria distribution and abundance in the spanish water reservoirs during thermal stratification. Limnetica, 23(1-2):119-132.

DIXIT, S. S., A. S. DIXIT \& J. P. SMOL. 2002. Diatom and chrysophyte transfer functions and inferences of post-industrial acidification and recent recovery trends in Killarney lakes (Ontario, Canada). J. Paleolimnol., 27: 79-96.

ENACHE, M. \& Y. T. PRAIRIE. 2002. WA-PLS diatom-based $\mathrm{pH}, \mathrm{TP}$ and DOC inference models from 42 lakes in the Abitibi clay belt area (Quebec, Canada). J. Paleolimnol., 27: 151-171.

JONES, V. J., R. J. FLOWER, P. G. APPLEBY, J. NATKANSKI, N. RICHARDSON, B. RIPPEY, A. C. STEVENSON \& R. W. BATTARBEE. 1993. Palaeolimnological evidence for the acidification and atmospheric contamination of lochs in the Cairngorm and Lochnagar areas of Scotland. $J$. Ecol., 81: 3-24.

JOYNT III, E. H. \& A. P. WOLFE. 2001. Paleoenvironmental inference models from sediment diatom assemblages in Baffin Island lakes 
(Nunavut, Canada) and reconstruction of summer water temperature. Can. J. Fish. Aquat. Sci., 58: 1222-1243.

KRAMMER, K. \& H. LANGE-BERTALOT. 1991a. Bacillariophyceae 3 Teil: Centrales, Fragilariaceae, Eunotiaceae. In: Sübwasserflora von Mitteleuropa. Band 2/3. Ettl, H., J. Gerloff, H. Heynig \& D. Mollenhauer (eds.). Gustav Fischer Verlag. Stuttgart-Jena. 576 pp.

KRAMMER, K. \& H. LANGE-BERTALOT. 1991b. Bacillariophyceae 4 Teil: Achnanthaceae, Kritische Ergänzungen zu Navicula (Lineolatae) und Gomphonema Gesamtliteraturverzeichnis Teil 1-4. In: Sübwasserflora von Mitteleuropa. Band 2/4. Ettl, H., G. Gärtner, J. Gerloff, H. Heynig \& D. Mollenhauer (eds.). Gustav Fischer Verlag. Stuttgart-Jena. 436 pp.

KRAMMER, K. \& H. LANGE-BERTALOT. 1997a. Bacillariophyceae 1 Teil: Naviculaceae. In: Sübwasserflora von Mitteleuropa. Band 2/1. Ett., H, J. Gerloff, H. Heynig \& D. Mollenhauer (eds.). Gustav Fischer Verlag. Jena-Sttutgart-Lübeck-Ulm: 876 pp.

KRAMMER, K. \& H. LANGE-BERTALOT. 1997b. Bacillariophyceae 2 Teil: Bacillariaceae, Epithemiaceae, Surirellaceae. In: Sübwasserflora von Mitteleuropa. Band 2/2. Ett., H, J. Gerloff, H. Heynig \& D. Mollenhauer (eds.). Gustav Fischer Verlag. Jena-Sttutgart-Lübeck-Ulm. 610 pp.

LEPISTÖ, L. \& U. ROSENSTRÖM. 1998. The most typical phytoplankton taxa in four types of boreal lakes. Hydrobiologia, 369/370: 89-97.

LOTTER, A. F. 1998. The recent eutrophication of Baldeggersee (Switzerland) as assessed by fossil diatom assemblages. The Holocene, 8(4): 395-405.

MARGALEF, R., D. PLANAS, J. ARMENGOL, A. VIDAL, N. PRAT, A. GUISET, J. TOJA \& M. ESTRADA. 1976. Limnología de los embalses españoles. Dirección General de Obras Hidráulicas Ministerio de Obras Públicas. Madrid. 452 pp.

NEGRO, A. I., C DE HOYOS \& J. C. VEGA. 2000. Phytoplankton structure and dynamics in Lake Sanabria and Valparaíso reservoir (NW Spain). Hydrobiologia, 424: 25-37.

NEGRO, A. I., C. DE HOYOS \& J. J. ALDASORO. 2003. Diatom and desmid relationships with the environment in mountain lakes and mires of NW Spain. Hydrobiologia, 505 (1-3): 1-13.

PARSONS, T. R. \& J. D. H. STRICKLAND., 1963. Discussion of spectrophotometric determination of marine plant pigments, with revised equations for ascertaining chlorophyll and carotenoids. J. Mar. Res., 21: 155-163.

PLANAS, D. 1975. Distribution and productivity of the phytoplankton in Spanish reservoirs. Verh. Internat. Verein. Limnol., 19: 1860-1870.

RACCA, J. M. J., A. PHILIBERT, R. RACCA \& Y. T. PRAIRIE. 2001. A comparison between diatombased $\mathrm{pH}$ inference models using Artificial Neural Networks (ANN), Wighet Averaging (WA) and Wighted Averaging Partial Least Squares (WAPLS) regresions. J. Paleolimnol., 26: 411-422.

REAVIE, E. D., J. P. SMOL, I. D. SHARPE, L. A. WESTENHOFER \& A. M. ROBERTS. 2000. Paleolimnological analyses of cultural eutrophication patterns in British Columbia lakes. Can. J. Bot., 78: 873-888.

RIERA, J. L.; D. JAUME, J. DE MANUEL, J. A. MORGUI \& J. ARMENGOL. 1992. Patterns of variation in the limnology of Spanish reservoirs: A regional Study. Limnetica, 8: 111-123.

SABATER, S. 1991. Size as a factor in centric diatoms distribution: the spanish reservoirs as an example. Oecologia aquatica, 10: 45-60.

SABATER, S. \& J. NOLLA. 1991. Distributional patterns of phytoplankton in Spanish reservoirs: First results and comparison after fifteen years. Verh. Internat. Verein. Limnol., 24: 1371-1375.

SIVER, P. A., A. M. LOTT, E. CASH, J. MOSS \& L. J. MARSICANO. 1999. Century changes in Connecticut, U.S.A., lakes as inferred from siliceous algal remains and their relationships to landuse change. Limnol. Oceanogr., 44(8): 1928-1935.

SOURNIA, A. (Editor). 1978. Phytoplankton manual. UNESCO, UK. 337 pp.

STEVENSON, A. C., H. J. B. BIRKS, R. J. FLOWER \& R. W. BATTARBEE. 1989. Diatom-based $\mathrm{pH}$ reconstruction of lake acidification using Canonical Correspondence Analysis. Ambio, 18(4): 228-233.

STOERMER, E. F. \& J. P. SMOL (ed.). 1999. The Diatoms: Applications for the Environmental and Earth Sciences. Cambridge, U.K.: Cambridge University Press. 469 pp.

TEMPONERAS, M., J. KRISTIANSEN \& M. MOUSTAKA-GOUNI. 2000. Seasonal variation in phytoplankton composition and physical-chemical features of the shallow Lake Doïrani, Macedonia, Greece. Hydrobiologia, 424: 109-122.

TER BRAAK, C. J. F. 1986. Canonical correspondence analysis: a new eigenvector technique for multivariate direct gradient analysis. Ecology, 67(5): 1167-1179. 
TER BRAAK, C. J. F. 1987. Ordination. In: Data analysis in community and landscape ecology. R. H. Jongman, C. J. F. ter Braak \& O. F. R. van Tongeren (eds.): 91-173. Pudoc, Wageningen, The Netherlands.

TER BRAAK, C. J. F. \& P. SMILAUER. 1998. CANOCO reference Manual and user's guide to Canoco for Windows: Software for Canonical Community Ordination (version 4). Microcomputer Power. Ithaca, New York. USA. 352 pp.
TOLONEN, K. \& T. JAAKKOLA. 1983. History of lake acidification and air pollution studied on sediments in South Finland. Ann. Bot. Fennici, 20: 57-78.

UTERMÖHL, H. 1958. Zur Vervollkommnung der quantitativen Phytoplankton-Methodik. Mitt. Int. Ver. Theor. Angew. Limnol., 9: 1-38.

VERSCHUREN, D., KATHLEEN, T. L. \& B. F. CUMMING. 2000. Rainfall and drought in equatorial east Africa during the past 1,100 years. Nature, 403: 410-414. 